\title{
Metaphorical Role of Animals in Myanmar Proverbs and Myanmar Society
}

\author{
Aung Ko Ko Min ${ }^{1}$, Mya Thida ${ }^{2}$
}

\author{
${ }^{1}$ Department of English, National Management Degree College, Myanmar \\ ${ }^{2}$ Department of Language, University of Computer Studies (Hinthada), Myanmar
}

\begin{abstract}
This paper deals with discovering how animals are important in building metaphors in Myanmar proverbs and the role of these animals in Myanmar society and culture. The purpose of the study is to investigate which animals are used in Myanmar proverbs, what are the most common animals used in these proverbs and the role these animals play in everyday life of Myanmar People. The findings reveal that there are 291 metaphors used for 40 animals in 251 proverbs. These animals include domestic animals, wild animals, insects and also mythical creatures such as Dragon and Garuda. The most common animals are birds, fish, elephant, cattle, tiger, dog, chicken, cat, mouse and buffalo. Popular and prominent examples of these ten most common animals are put forward for interpretation under The Contemporary Metaphor Theory and it is found out that the animal metaphors describe a lot about the conceptual mind of Myanmar people and Myanmar historical, geographical, cultural, social, economic and religious conditions.
\end{abstract}

Keywords-Animals, Metaphors, Myanmar Proverbs, Role \& Society.

\section{INTRODUCTION}

There are different types of sayings in human languages such as proverbs, maxims, adages, idioms and clichés. Among them proverbs are of great importance in studying the people and culture of a nation. And not every form of saying is recognized or acknowledged as proverbs. Various scholars try to characterize proverbs in order to differentiate them from other figures of speech. Therefore, Prahlad (1996:33) asserted, "True proverbs must further be distinguished from other types of proverbial speech." Pe, H. (1962:11) standardized the attributes of a proverb as "the style of a proverb must be epigrammatic and the intention underlying the proverb is to give advice or warning or to hand on a piece of wisdom." Thus it is obvious that the task of defining a proverb is not easy and straightforward. Proverbs are metaphorical i.e. people understand one thing in terms of another. The things, objects or images in proverbs are representations of people or abstract ideas that we want to refer to. "It is a system of metaphor that structures our everyday conceptual system, including most abstract concepts, that lies much of everyday language.” (Lakoff, 1992:3)

Myanmar is an ASEAN country which is rich in culture and tradition. And this well-off tradition and culture is the breeding ground of abundance of proverbs, sayings and adages in the life of Myanmar people. Myanmar proverbs ISSN: 2456-7620 come from the experiences of everyday life, traditional folklores and the stories of Buddha's existences in previous lives because Buddhism is the major religion of Myanmar. These proverbs give a lot of information about Myanmar history, geography, economy, society and religion. Consequently Myanmar proverbs become an indispensable part in learning about Myanmar and its people. Among them, animal proverbs constitute a large portion. Different types of animals are used in Myanmar proverbs to depict human characters, behaviours and relationships. This study aims to investigate the metaphorical role of animals in Myanmar proverb: which animals are used in constructing metaphors in Myanmar proverbs, which are the most common animals in proverbs and how they reflect Myanmar's conceptual mind in historical, geographical, cultural, economic and religious background.

\section{LITERATURE REVIEW}

Pe, H. (1962) put Myanmar proverbs into five categories: human characteristics, human behaviours, human relationships, world and man. But he added that a proverb may have more than one implication.

Sharifi (2012) explored the role of body members in constructing metaphors in Persian political texts. She discovered 15 different parts of human body on which 
political metaphors were conceptualized and that 'head' is the most frequently conceptualized one.

Kobia (2016) analyzed chicken metaphors in Swahili Proverbs using the Conceptual Metaphor Theory. His study revealed that chicken was associated with positive connotations in Swahili community like caring, protective, motherly, gentle, and peaceful. He also found out some negative characteristics like cowardice, foolishness, deceitfulness, laziness, stupidity, worthlessness, ignorance, being easily manipulated, dullness and promiscuousness.

Ni, T. (2019) compared 11 animal proverbs of Myanmar with their English counterparts to find out the cultural differences in the concept of animals. She discovered that some proverbs in the two languages are identical in meaning but are different in animal images and some are identical in both meaning and animal images.

Thin, P. P. (2019) compared 100 proverbs each from English and Myanmar and found out that there were 52 English and Myanmar proverbs that share similar underlying meaning. She assumed seven of these proverbs to be borrowings or imports.

\section{METHODOLOGY}

Animal proverbs in this study were collected from "Myanmar Proverbs and Sayings" by Pyinyar Kyaw (2009), "Burmese Proverbs" by Dr Hla Pe (1962) and Wikipedia. The research was conducted by using both quantitative and qualitative approaches. For quantitative method, the researchers picked out 291 metaphors from 251 animal proverbs (some proverbs contain more than one animal referents) and sorted them into categories in terms of animals to which they belong. Then a frequency table was drawn for ordering these animals according to the number of metaphors used for them. For qualitative method, ten most common animals used in Myanmar proverbs were selected and interpreted within The Contemporary Metaphor Theory by Lakoff (1993) and then their metaphorical importance was explained in geographical, historical, economic, religious and sociocultural conditions of Myanmar.

\section{FINDINGS AND DISCUSSION}

We analyzed a corpus of 251 Myanmar proverbs that use animal metaphors and it was discovered that there are 40 different kinds of animals comprising domestic animals wild animals, insects and also such mythical creatures as Dragon and Garuda. There are a total of 291 metaphors derived from source domain of these animals. The most common animals used for metaphorical purpose in
Myanmar proverbs are found to be different kinds of birds including mythical ones (31 occurrences), different types of fish (29 occurrences), elephant (28 occurrences), cattle (27 occurrences), tiger (24 occurrences), dog (18 occurrences), Chicken (16 occurrences), cat (15 occurrences), mouse (14 occurrences) and buffalo (9 occurrences). The results are shown in the 'Table' below.

Fig.1: Frequency of Animal Metaphors in Myanmar Proverbs

\begin{tabular}{|c|c|c|}
\hline Animals & $\begin{array}{l}\text { Number of } \\
\text { metaphors }\end{array}$ & $\begin{array}{c}\text { Frequency } \\
\text { (percentage) }\end{array}$ \\
\hline Bird & 31 & $10.7 \%$ \\
\hline Fish & 29 & $10.0 \%$ \\
\hline Elephant & 28 & $9.6 \%$ \\
\hline Cattle & 27 & $9.3 \%$ \\
\hline Tiger & 24 & $8.2 \%$ \\
\hline Dog & 18 & $6.2 \%$ \\
\hline Chicken & 16 & $5.5 \%$ \\
\hline Cat & 15 & $5.2 \%$ \\
\hline Mouse & 14 & $4.8 \%$ \\
\hline Buffalo & 9 & $3.1 \%$ \\
\hline Rabbit & 8 & $2.7 \%$ \\
\hline Snake & 7 & $2.4 \%$ \\
\hline Horse & 6 & $2.1 \%$ \\
\hline Monitor lizard & 5 & $1.7 \%$ \\
\hline Pig & 4 & $1.4 \%$ \\
\hline Deer & 4 & $1.4 \%$ \\
\hline Frog & 4 & $1.4 \%$ \\
\hline Bee & 4 & $1.4 \%$ \\
\hline Dragon & 3 & $1.0 \%$ \\
\hline Lion & 3 & $1.0 \%$ \\
\hline Goat & 3 & $1.0 \%$ \\
\hline Shrimp & 3 & $1.0 \%$ \\
\hline Snail & 3 & $1.0 \%$ \\
\hline Crocodile & 2 & $0.7 \%$ \\
\hline Muntjac & 2 & $0.7 \%$ \\
\hline Monkey & 2 & $0.7 \%$ \\
\hline Scorpion & 2 & $0.7 \%$ \\
\hline Ant & 2 & $0.7 \%$ \\
\hline Maggot & 2 & $0.7 \%$ \\
\hline
\end{tabular}




\begin{tabular}{|c|l|l|}
\hline Banteng & 1 & $0.3 \%$ \\
\hline Jungle cat & 1 & $0.3 \%$ \\
\hline Mongoose & 1 & $0.3 \%$ \\
\hline Turtle & 1 & $0.3 \%$ \\
\hline Bat & 1 & $0.3 \%$ \\
\hline Chameleon & 1 & $0.3 \%$ \\
\hline Squirrel & 1 & $0.3 \%$ \\
\hline Centipede & 1 & $0.3 \%$ \\
\hline Moth & 1 & $0.3 \%$ \\
\hline Termite & 1 & $0.3 \%$ \\
\hline Fly & 1 & $0.3 \%$ \\
\hline
\end{tabular}

Using the translation in "Burmese Proverbs" by Dr Hla Pe, the most common and popular examples of proverbs for each of these ten most frequently used animals were brought up for explanation and interpretation within the tenets of The Contemporary Metaphor Theory.

\subsection{Bird}

(1) A good tree can lodge ten thousand birds.

This is a proverb that reflects human relationship (Hla Pe, 1962). Here a good tree refers to a wealthy and affluent person and birds are the source domains for another domain "relatives". It is a Myanmar tradition that a rich and prosperous person looks after other relatives with money or properties. The proverb means that if a person among their relatives becomes rich, the other relatives can rely on him or her.

(2) Crow-peasant respects crow, and crow respects crowpeasant.

This is another proverb that portrays human relationship. Crow-peasant and crow are used to refer to human beings of different status. The proverb means that people should respect each other regardless of different social status.

(3) A parrot is golden on a golden tree, silver on a silver tree.

The proverb is about reflected glory (Hla Pe, 1962). Here a person who becomes famous or rich not because of his own effort or work or ability but on account of others' glory or work is talked of as a parrot that shines because of the golden or silver tree that it perches on.

(4) The sparrow was hit by the stone before.

In this proverb the sparrow refers to someone who has been hurt once in their life. The meaning is that as one has already faced a danger and suffered a lot, he is cautious not to suffer it again.

ISSN: 2456-7620
(5) He is told it's a crane and he asks: "What kind of bird is it?

Ignorance in human character is depicted in this proverb. It's about people who are stupid or ignorant. Although they have already told about something, they cannot see or understand it because of their stupidity of negligence.

Myanmar proverbs are rich in bird metaphors. This may be because Myanmar has been and is rich in natural tropical forests which home different species of tropical birds. According to Wikipedia, there are a total of 1135 species of birds recorded in avifauna of Myanmar. These different types of birds have played and are still playing an important role in everyday life of Myanmar people. Bird metaphors are used in Myanmar proverbs to depict human nature, character and behaviour. Birds are social animals that lives in flocks and Myanmar people use birds as metaphorical image to talk about human society and human relationships.

\subsection{Fish}

(6) At the sight of the fresh fish away goes the roast.

This is a proverb about marriage life (Hla Pe, 1962). It portrays unfaithfulness in marriage partners and human nature of getting bored easily, not enjoying what he has and looking for a new one. Here the fish refers to a spouse. One who gets rid of an old spouse seeing a new partner is talked of as throwing the roasted fish in the prospect of a fresh fish.

\section{(7) The whole boat is putrid because of a single carp.}

This is one of the fish proverbs that describe the nature of society and human relationship. The carp in the proverb is a referent of a bad person as with a black sheep in English. It depicts how the misconduct of a single person affects the whole society. People who are related to that person can suffer because of his bad reputation.

(8) Even roasting fish-paste calls for a teacher's guidance.

This proverb talks about the role and importance of teachers. Fish-paste is the favourite food of Myanmar people. It always takes its place on Myanmar dining room table. Roasting fish-paste is not such a difficult task. But without the guidance of a teacher, one cannot even roast fish-paste properly. The proverb reflects Myanmar culture in which teachers are highly respected.

\section{(9) A motherless son is a fish in low water.}

The proverb illustrates how a mother is important for a son. Here the fish is the metaphor of the son. Mother is essentially important for bring up a son. As a fish in shallow water gets trouble with mobility so also is a 
motherless son in community. He always has to feel small and unconfident.

\section{(10) He cast the net only when the fish had gone off.}

This proverb teaches how one should grasp opportunity only when it is available. The fish is the source domain for the target domain "chance". The meaning is that it is pointless agonizing when there is no more chance.

Myanmar is a land of rivers and streams and it is also bounded by the Bay of Bengal in the west and the Andaman Sea in the south. Accordingly it abounds with a variety of fish and fishery has been and is one of the main economies of the country and fish plays a large role in Myanmar food. Myanmar people beat fish into paste and cook it in various ways eat with relish. Fish is used metaphorically in Myanmar proverbs to describe human traits, characters, behaviours and relationships. Fish proverbs not only teach moral lessons on how to live and behave in the world but express truths about the world.

\subsection{Elephant}

(11) He leans on the white elephant and sucks sugarcane.

This proverb shows how some people get affluent or famous or powerful on account of the ones they rely on. It is one of the proverbs about reflected glory. The white elephant in this proverb is the image of a superior or great person that is a man of power or fortune or wisdom.

(12) The black elephant dare not look at the royal white elephant's face.

The black elephant here is a referent of a wicked or crooked person and the royal white elephant is a noble or wise man. Dishonest people feel insecure in front of the good and virtuous ones and so they are afraid of looking into their eyes worrying that their crookedness will be revealed.

\section{(13) When an elephant shrinks it's still a buffalo.}

When an elephant becomes thin it is still as fat as a buffalo. The underlying meaning of the proverb is that even when a man of enormous wealth gets poor, he is still as rich as those of an average wealth. Elephant is the image of wealth or affluence or power in Myanmar.

(14) The prospect of getting a white elephant is cancelled by the receipt of a single (white) cotton thread.

This reflects Myanmar People's belief that how one's luck of receiving a big gift can spoil if he accepts a small one. Here again the white elephant is a connotation for prosperity.

(15) The price of the hook (goad) is higher than the price of the elephant.
This saying portrays the contradiction of how the extras are more expensive than the main object. The elephant is the referent of the main item we want to buy and the hook denotes the accessories we need to buy as supplements. Sometimes it is paradoxical that supplements cost more than the main object.

Myanmar possesses a large population of Asian elephants in South East Asia being between 4,000 and 5,300 (Sukumar, 2006). Therefore elephant metaphors influence Myanmar language and literature. Elephant proverbs of Myanmar mirror the history, culture, beliefs and economy of Myanmar. Myanmar people use elephants for various purposes: logging, agriculture, transportation tourism and religious ceremonies. Elephant is the image of strength and prosperity. White elephant is highly valued by Myanmar people as a royal treasure. The main religion of Myanmar is Buddhism. It is believed that Buddha reincarnated as a white elephant in one of his existences before he became a Buddha (Hla Pe, 1962). In Myanmar history, Myanmar monarchical kings used to be proud of the number of white elephants they possess as they believe these animals will make them more powerful and add glory to a kingdom. You can see the white elephant's figure on larger notes of Myanmar currency. Elephant in Myanmar culture is the figure of strength, wealth, sacredness, glory and impression.

\subsection{Cattle}

\section{(16) If the cattle are scattered the tiger sizes them.}

It has the same meaning as "Unity is strength". Cattle are social animals so also are men. As the herd of cattle is broken, it is easier for the tiger to catch them. When people are not united, it is like inviting the enemy to come.

(17) The strongest young bullock is only as strong as an old bullock with a broken leg.

The bullock in this proverb is a referent of a man. The word "strong" here probably means mental strength rather than physical strength. For Myanmar people, to be older is to be wiser because they have more experience than younger people. So the wisest youth is only as wise as the old man with little knowledge and wisdom. However this proverb is also used in modern Myanmar society to refer to physical strength when old men are debating with the young.

\section{(18) A village ox never feeds on village grass.}

This proverb is a portrait on human nature of not having interest in familiar things. The village ox refers to a village boy and the grass is the referent of a village girl. Village boys do not usually court the girls of the same village because they have long been friends since childhood. The 
main economy of Myanmar village people is agriculture and cattle have long been coworkers of people in rural areas using the traditional method of farming. Therefore it is not unusual that village boys are characterized by ox in rural societies.

(19) The bullock is handsome if a Shan likes it: a bed is a palace if you fancy it.

This proverb is equal to "Beauty is in the eye of the beholder" in English. Shan are one of the national races living in Eastern part of Myanmar. "The Shan people are great cattle-fanciers (Hla Pe, 1962)". Everyone is handsome or pretty for the person who likes them. Here the source domain bullock is used for the target domain marriage partner.

\section{(20) Old bullocks are partial to tender grass.}

Old bullocks are connotations for old men and tender grass is a referent of young women. In Myanmar culture the proverb is used in negative sense to blame those who want to marry young ladies only when they become old.

Myanmar is an agricultural country and farmers have long raised animals such as cattle, horses and buffalos for farming. Therefore cattle have become one of the oldest friends and coworkers of Myanmar people. But Myanmar people see these animals as dull or unintelligent beings. Metaphors relating to cattle in Myanmar proverbs are usually employed negatively to contemn or scorn other people.

\subsection{Tiger}

(21) Being afraid of the tiger he takes refuge with the lord Spirit, but the lord Spirit is worse than the tiger.

The tiger in this proverb denotes an evil and cruel person and the lord Spirit is an image for the person who is responsible for that evil man. This means that we count on some people for help when we are threatened by unscrupulous ones but we later know that the ones we rely on for help are even more dangerous. Although Myanmar people mainly worship Buddhism, they also take refuge with traditional spirits which are called "Nats". It is believed that tigers are paraphernalia of the spirits.

\section{(22) A lucky tiger! When it's running it finds a deer.}

The lucky tiger in this proverb is a lucky man who meets opportunity by chance. Tigers are looked upon as strong and powerful but deer are thought of as meek and mild in the mind of Myanmar people.

\section{(23) The tiger who courts death moves to another jungle.}

The tiger that moves to another jungle is used to mention a man who, looking down upon one's own country, migrates to a foreign country and faces trouble.
(24) Where there are bold tigers about you are not justified in blaming your fate.

The meaning is that you are not to blame your fate when you get into trouble for doing something risky even if you know it. Myanmar people traditionally believe in fate and so the proverb teaches them not to always blindly depend on fate.

\section{(25) The hero appears only when the tiger is dead.}

The proverb is about cowardice. Here the tiger is the connotation for a dangerous enemy or a dangerous condition. This proverb demonstrates how coward men dare not show themselves up at the time of fighting, battle or struggle but they come out only when the enemy dies or the catastrophe is over to claim to be heroes.

The abundance of tiger proverbs in Myanmar culture proves how Myanmar has possessed a plenty of these wildlife animals throughout history. Wildlife Conservation Society Myanmar (WCS) says that Myanmar is one of the 13 countries in Mainland Asia that continues to have tigers to the present day. Tiger is the representation of danger, cruelty, viciousness and ferocity in Myanmar culture. Tiger proverbs in Myanmar describe human character, behaviour, relationship and belief.

\subsection{Dog}

\section{(26) It (dog) sleeps on leather and gnaws the edges.}

It equals in meaning to "To bite the hand that feeds it" in English. Here the dog represents an ungrateful person who does not know or appreciate the gratitude of others.

\section{(27) The dog may bark but the ant-hill will not run away.}

It is similar in meaning to "The dog barks but the caravan goes on." The barking dog refers to a loud-mouthed person who is pessimistic towards good and noble people and talks bad things about them. However he is not able to harm the reputation of these virtuous people.

\section{(28) Fondle a dog and it will lick your face.}

It means that if you favour a dog, it will take advantage of your favour and lick your face. The proverb says that you should not give favour to those do not know the difference in status. If you do, they will not see their inferior status and try to equate themselves with you.

Myanmar people keep dogs as domestic animals mainly for guarding their house and farm and less commonly for hunting. Thus dogs have become friends of Myanmar people for long. Nevertheless, dogs are thought of as dirty, disgusting and lacking in good characteristics and they are only kept at doorsteps or underneath the house or in the compound and they are not welcome at such grand places at living room or bedroom. In conversations of Myanmar's 
everyday life dog metaphors are mostly used in the negative sense to contemn or condemn those people who do not deserve good regards of respect.

\subsection{Chicken}

(29) A blind fowl came upon the rice-pot.

The blind fowl in this proverb represents an unable or disable person and the rice-pot is the metaphor of good opportunity. The implication is that although some people are not able, they are lucky enough to meet with opportunity by chance.

(30) Day will not break for a hen's cackle; it will break only for a cock's crow.

Here the hen is a referent of a woman and the cock is the source domain for the target domain men. This proverb reflects how Myanmar was and is a male-dominant society. In Myanmar history there was only one Queen 'Shin Sawbu (1454-1471)' and all the others are monarchical kings. In Myanmar society, men are considered superior, abler and more powerful than women. Women were held in the secondary place to men. And their importance was confined to household duties. This attitude is still held by some people today although there have been a lot of changes in social and political views.

(31) With fowls, the pedigree, with men, breeding.

This proverb shows how the history of a family is important in judging or evaluating people. Here fowls are identified with men in terms of how their breeding is important in assessing them. In Myanmar culture and tradition when a man is engaging with a woman, the usual question asked by the woman's parents to the man is 'Who are your parents and relatives?'

Chicken proverbs also show human character, human behaviour and relationship. The image of cocks and hens are usually used in Myanmar society to refer to men and women.

\subsection{Cat}

(32) Because the cat's away, the mice are at play.

The cat refers to a person in charge (e.g. a teacher or a parent or a boss) and mice are the source domain for the target domain people who are under the charge of that person (e.g. students or children or employees). The proverb means that people are usually undisciplined in the absence of the one who is responsible for them.

(33) The snare was set to catch a hare but the cat was caught.

Cat is the common pet of Myanmar people and it is used as a referent of a member of the family especially one who relates to us by blood. The proverb means that one plans an ISSN: 2456-7620 action for other people to suffer but it is one's own flesh and blood that is hurt by the action that one plans.

\subsection{Mouse}

(34) Setting fire to the granary because one cannot beat the mice.

This means 'Burn one's house to get rid of the mice' in English. The proverb is about displacement in Sigmund Freud's defense mechanisms "Satisfying an impulse (e.g. aggression) with a substitute object (Freud, 1984, 1896)." When one cannot revenge on a person who is stronger than him, he tries to hurt others who are weaker than him for his satisfaction.

\section{(35) Mice cease to fear the cat when she is too old.}

Again in this proverb mice represent those who are under the charge and the cat is the one who is in charge. This demonstrates how an old master is less respected by young pupils. The proverb can be employed to talk about the relationship between parents and children, and a boss and employees.

In Myanmar cat proverbs usually include mice metaphors and vice versa. This may be because mouse is cat's food and the main purpose for Myanmar people for having cats at home is to keep the mouse away. Cat is a pet but mouse is a pest for Myanmar people. Mice are the nuisance not only at home by stealing the food in the kitchen, tearing off the clothes and carrying diseases but also on farm by destroying the crops. Mice in Myanmar proverbs are often used to talk about undisciplined and mischievous students, children or employees.

\subsection{Buffalo}

\section{(36) Playing a harp before a buffalo.}

It means 'To cast pearls before swine' in English. Buffalo is the source domain for the target domain a dumb or a dull person. The proverb illustrates how it is futile to say serious words to a stupid man who cannot understand or appreciate them or who pays no heed to them.

(37) He would like to ride a difficult buffalo but hasn't enough courage.

The buffalo in this proverb represents a dangerous man or a difficult task. The proverb is used to blame those coward men who claim to do a big job but have no courage or ability to do.

As mentioned above Myanmar is an agricultural country and people raise cattle and buffalo as farm animals. Accordingly these animals played an important role in the agricultural sector of Myanmar, whereupon they played a key role in everyday and cultural life of Myanmar as metaphorical images. Despite their usefulness and 
helpfulness in work, these animals are characterized as dumb, dull, stupid and naive creatures. This view is reflected in Myanmar proverbs.

\section{CONCLUSION}

Myanmar people use a lot of proverbs and sayings in their everyday conversation and literature, and animal proverbs form a large component of them. Thus animals are essentially important in creating metaphorical concepts in language. The results of this study revealed that there are forty different types of animals used in Myanmar proverbs and the most common animals are birds, fish, elephant, cattle, tiger, dog, chicken, cat, mouse and buffalo. The metaphors derived from these animals reflect the conceptual mind of Myanmar people and animal proverbs play an important role in understanding the history, culture, geography, economy, and religion of Myanmar people. This paper will be a good support for those who are studying conceptual metaphors and proverbs and those who are interested in learning about Myanmar culture, tradition and society. However the proverbs in this research were collected from three important sources mentioned in the methodology section and there may be a few proverbs about animals not included in calculation but they may be little-known to Myanmar people. Moreover, only ten most common animals were chosen with selected examples for interpretation and discussion in case the scope of study is too broad. Therefore it is advisable for other researchers to carry on the search with other animals for fuller discovery of Myanmar people and their conceptual mind.

\section{REFERENCES}

[1] Kobia, J.M. (2016). A Conceptual Metaphorical Analysis of Swahili Proverbs with Reference to Chicken Metaphor.

[2] Lakoff, G. (1993). The contemporary theory of metaphor. In A. Ortony (Ed.), Metaphor and thought (p. 202-251). Cambridge University

[3] Lakoff, G., \& Johnson, M. (2003). Metaphors we live by. Chicago: University of Chicago Press

[4] McLeod, S. A. (2018, April 05). What are the most interesting ideas of Sigmund Freud?. Simply Psychology. https://www.simplypsychology.org/Sigmund-Freud.html

[5] Ni, T. (2019). Cultural Awareness through Animal Proverbs in English and Myanmar. World Journal of Research and Review. 9. 10.31871/WJRR.9.2.13.

[6] Pe, H. (1962). Burmese Proverbs. London: UK Press.

[7] Pyinnyarkyaw. (2009). Myanmar Proverbs and Sayings. Yangon: Unity Press.

[8] Sharifi, Shahla \& Pooresfahani, Ailin \& Pooresfahani, Aida. (2012). Role of Body Members in Constructing Metaphors in Persian Political Texts. Mediterranean Journal of Social Sciences. 3. 10.5901/mjss.2012.v3n3p171.
[9] Sukumar, Raman. (2006). A brief review of the status, distribution and biology of wild Asian elephants Elephas maximus. International Zoo Yearbook. 40. 1 - 8 . 10.1111/j.1748-1090.2006.00001.x.

[10] Sw. Anand Prahlad. 1996. African-American Proverbs in Context. Jackson: University Press of Mississippi.

[11] Thinn, P.P. (2019). A Comparative Study of English and Myanmar Proverbs from Cultural Point of View. 